\title{
Transcriptomic Profiling of the Four Adenosine Receptors in Human Leukocytes of Heart Failure Patients
}

\author{
Manuela Cabiati, ${ }^{1}$ Raffaele Caruso, ${ }^{2}$ Alessandro Verde, ${ }^{3}$ Laura Sabatino, ${ }^{1}$ \\ Maria-Aurora Morales, ${ }^{1}$ and Silvia Del Ry ${ }^{1}$ \\ ${ }^{1}$ Laboratory of Cardiovascular Biochemistry, CNR Institute of Clinical Physiology, Via Giuseppe Moruzzi 1, 56124 Pisa, Italy \\ ${ }^{2}$ CNR Institute of Clinical Physiology, 20162 Milan, Italy \\ ${ }^{3}$ Cardiovascular Department, Niguarda Ca' Granda Hospital, 20162 Milan, Italy
}

Correspondence should be addressed to Silvia Del Ry; delry@ifc.cnr.it

Received 18 April 2013; Revised 17 May 2013; Accepted 22 May 2013

Academic Editor: Ahmed Abdel-Latif

Copyright (C) 2013 Manuela Cabiati et al. This is an open access article distributed under the Creative Commons Attribution License, which permits unrestricted use, distribution, and reproduction in any medium, provided the original work is properly cited.

\begin{abstract}
In this study the transcriptomic profiling of adenosine receptors (ARs) in human leukocytes of heart failure (HF) patients as a function of clinical severity, assessing the possible changes with respect to healthy subjects $(C)$, was evaluated. Total RNA was extracted from leukocytes of $C(n=8)$ and of HF patients (NYHA I-II $n=9$; NYHA III-IV $n=14)$ with a PAXgene Blood RNA Kit. An increase as a function of clinical severity was observed in each AR $\left(\mathrm{A}_{1} \mathrm{R}: C=0.02 \pm 0.009, \mathrm{NYHA}\right.$ I-II $=0.21 \pm 0.09$, NYHA III-IV $=3.6 \pm 1.3, P=0.03 C$ versus NYHA III-IV, $P=0.02$ NYHA I-II versus NYHA III-IV; $A_{2 \mathrm{a}} \mathrm{R}: C=0.2 \pm 0.05$, NYHA I-II $=0.19 \pm 0.04$, NYHA III-IV $=1.32 \pm 0.33, P=0.005 C$ versus NYHA III-IV, $P=0.003$ NYHA I-II versus NYHA III-IV; $A_{2 b}$ R: $C=1.78 \pm 0.36$, NYHA I-II $=1.35 \pm 0.29$, NYHA III-IV $=4.07 \pm 1.21, P=0.03$ : NYHA I-II versus NYHA IIIIV; $\mathrm{A}_{3} \mathrm{R}: C=0.76 \pm 0.21$, NYHA I-II $=0.94 \pm 0.19$, NYHA III-IV $=3.14 \pm 0.77, P=0.01 C$ versus NYHA III-IV and NYHA I-II versus NYHA III-IV, resp.). The mRNA expression of the ectonucleoside triphosphate diphosphohydrolase (CD39) and the ecto- $5^{\prime}$-nucleotidase (CD73) were also evaluated. They resulted up-regulated. These findings show that components of adenosine metabolism and signalling are altered to promote adenosine production and signalling in HF patients. Thus, HF may benefit from adenosine-based drug therapy after confirmation by clinical trials.
\end{abstract}

\section{Introduction}

Adenosine is a potent extracellular messenger produced in high concentrations under metabolically unfavorable conditions [1]. Adenosine restores tissue homeostasis through the interaction with its membrane receptors, acting as a retaliatory metabolite $[1,2]$.

In particular, adenosine receptors such as $\mathrm{A}_{2 \mathrm{a}} \mathrm{R}$ receptors can contribute to tissue repair by enhancing paracrine adaptive mechanisms, by improving engraftment of circulating progenitor cells, or by promoting proliferation and differentiation of bone marrow mesenchymal stem cells in vivo [3]. Moreover, the cells of the immune system express adenosine receptors and may be the basis of adenosine modulatory effects in an inflammatory environment.

The ability of adenosine to inhibit cardiac fibroblast proliferation and collagen synthesis may help attenuate cardiac remodelling and fibrosis of ischemic or failing hearts [3, 4], thus preserving cardiac tissue architecture. Adenosine also shows an endogenous calcium antagonist-like effect, reducing the effects of calcium overload in the failing heart [5-7].

Despite great advances in the field of pharmacological and nonpharmacological treatment, at present [8], the rising epidemic of heart failure (HF) is an enormous medical and societal burden, since it affects $1 \%-2 \%$ of the adult population in western countries and $\geq 10 \%$ of the elderly population [9]. Therefore, greater knowledge of the mechanisms underlying the process of HF in all its multifactorial aspects is strongly warranted, also on a molecular basis.

Based on previous studies showing that in cardiovascular disease human circulating blood cells may mirror the same abnormalities occurring in the heart [10], studies have been carried out in peripheral blood mononuclear cells (PBMC) $[11,12]$, and recently $A_{1} R, A_{2 a} R, A_{2 b} R$, and $A_{3} R$ mRNA 
expression was evaluated in human whole blood of normal subjects [13]. The four adenosine receptor subtypes resulted simultaneously expressed in leukocytes of healthy adults [13], providing an important and useful starting point for future studies devoted to evaluating the expression of ARs in human diseases characterized by a marked inflammatory component.

The aim of this study was to evaluate the transcriptomic profiling of ARs in human leukocytes of HF patients as compared to healthy subjects and to assess whether this profiling is related to the clinical severity of the disease.

\section{Materials and Methods}

2.1. Blood Collection and RNA Extraction. The study conforms with the principles outlined in the Declaration of Helsinki approved in 1964. The study was approved by the local Ethical Committee, and all patients provided signed informed consent.

Human whole blood samples $(2.5 \mathrm{~mL})$ from eight healthy adults and from $23 \mathrm{HF}$ patients (New York Heart Classification-patients, NYHA I-II: $n=9$ and NYHA III-IV: $n=14$ ) were collected into PAXgene Blood RNA system (DIALAB ITALIA Srl) tubes.

The PAXgene Blood RNA system is an innovative new methodology for the collection, storage, and transport of blood, which efficiently stabilizes intracellular RNA and allows preservation of the samples at -20 to $-70^{\circ} \mathrm{C}$, maintaining the same degree of purity and stability of fresh blood.

Blood samples were processed with PAXgene Blood RNA kit (Qiagen, Milan, Italy) to obtain total RNA.

In all cases, the integrity of total RNA was detected by electrophoresis on Gel-Star (Lonza, Germany) stained 1.5\% Agarose (Bio-Rad, Milan, Italy) gel; total RNA purity and concentration were evaluated spectrophotometrically (NanoDrop, Celbio, Milan, Italy). The RNA samples were stored at $-80^{\circ} \mathrm{C}$.

In Table 1 the clinical and biochemical characteristics of HF patients are reported.

2.2. Reverse Transcription. A quantity of $0.5 \mu \mathrm{g}$ of total RNA obtained from each sample was reverse-transcribed with iScript cDNA Synthesis Kit (Bio-Rad, Milan, Italy) according to the manufacturer's instructions.

2.3. Primer Synthesis and Real-Time PCR. Specific primers for adenosine receptors were synthesized by Qiagen: $\mathrm{A}_{1} \mathrm{R}$ (Hs_ADORA1_2_SG Quantitect Primer assay), $\mathrm{A}_{2 \mathrm{a}} \mathrm{R}$ (Hs_ADORA2a_1_SG Quantitect Primer assay), $\mathrm{A}_{2 \mathrm{~b}} \mathrm{R}$ (Hs_ADORA2b_1_SG Quantitect Primer assay), and $\mathrm{A}_{3} \mathrm{R}$ (Hs_ADORA3_2_SG Quantitect Primer assay), while the ectonucleoside triphosphate diphosphohydrolase (CD39) and the ecto- $5^{\prime}$-nucleotidase (CD73) designated for the dephosphorylation of extracellular ATP to AMP were synthesized by sigma-Aldrich (Table 2). Following recent guidelines [14, 15], three (TOP2b, YWHAZ, and SRP14) candidate reference genes (Table 2), from among the most commonly cited in the literature and previously selected [16], were used to normalize mRNA expression data obtained by
TABLE 1: Clinical and biochemical characteristics of heart failure patients.

\begin{tabular}{|c|c|c|c|}
\hline & $\begin{array}{c}\text { Patients } \\
\text { NYHA I-II } \\
(n=9)\end{array}$ & $\begin{array}{c}\text { Patients } \\
\text { NYHA III-IV } \\
(n=14)\end{array}$ & $P$ \\
\hline Age, yrs & $54 \pm 4$ & $53 \pm 2$ & 0.801 \\
\hline Male, $n(\%)$ & $9(100)$ & $7(50)$ & 0.019 \\
\hline BMI, $\mathrm{kg} / \mathrm{m}^{2}$ & $26 \pm 3$ & $26 \pm 1$ & 0.557 \\
\hline Diabetes, $n(\%)$ & $1(11)$ & $3(21)$ & 1.000 \\
\hline Etiology, $n(\%)$ & & & 0.611 \\
\hline IDC & $8(89)$ & $10(71)$ & \\
\hline IHD & $1(11)$ & $4(29)$ & \\
\hline LVEDV, mL & $180 \pm 33$ & $268 \pm 29$ & 0.027 \\
\hline LVESV, mL & $128 \pm 29$ & $202 \pm 24$ & 0.055 \\
\hline LVEF, \% & $33 \pm 4$ & $26 \pm 2$ & 0.159 \\
\hline MID, $n(\%)$ & & & 0.074 \\
\hline 0 & $1(11)$ & - & \\
\hline $1+$ & $5(56)$ & $2(14)$ & \\
\hline $2+$ & $2(22)$ & $8(57)$ & \\
\hline $3+$ & $1(11)$ & $4(29)$ & \\
\hline $4+$ & - & - & \\
\hline LA area, $\mathrm{cm}^{2}$ & $20 \pm 2$ & $39 \pm 7$ & 0.007 \\
\hline \multicolumn{4}{|l|}{ Therapy, $n(\%)$} \\
\hline ACEi & $7(79)$ & $8(57)$ & 0.400 \\
\hline$\beta$-Blocker & $9(100)$ & $14(100)$ & 1.000 \\
\hline Statin & $4(44)$ & $7(50)$ & 1.000 \\
\hline Antiplatelets & $6(67)$ & $8(57)$ & 1.000 \\
\hline Diuretic & $7(78)$ & $14(100)$ & 0.142 \\
\hline $\begin{array}{l}\text { C-reactive protein, } \\
\mathrm{mg} / \mathrm{dL}\end{array}$ & $0.3 \pm 0.1$ & $0.8 \pm 0.3$ & 0.410 \\
\hline
\end{tabular}

Data are expressed as mean and SE or frequency (percentage).

BMI: body mass index; IDC: idiopathic dilated cardiomyopathy; IHD: ischemic heart disease; NYHA: New York Heart Classification; LVEDV: left ventricular end-diastolic volume; LVEF: left ventricular ejection fraction; LVESV: left ventricular end-systolic volume; MID: mitral insufficiency grade; LA: left atrium; ACEi: angiotensin converting enzyme inhibitor.

Real Time-PCR (RT-PCR) in human whole blood. Reaction conditions of reference gene primer pairs were optimized. For Quantitect Primer assays, manufacturer's Real-Time conditions were followed, and a gradient RT-PCR was conducted to assess the optimal annealing temperature, while a dilution curve was always generated to verify RT-PCR efficiency as also reported in a previous study [13].

RT-PCR reactions were performed in a 96-well CFX96 RT-PCR system (Bio-Rad). The reaction was carried out in a total volume of $25 \mu \mathrm{L}$ per reaction. Reaction mixture included $2 \mu \mathrm{L}$ of template cDNA, $1 \mu \mathrm{M}$ of each primer, $2 \mathrm{x}$ QuantiFast SYBR Green SuperMix (Bio-Rad), and sterile water. Amplification protocol started with $95^{\circ} \mathrm{C}$ for $3 \mathrm{~min}$ followed by 39 cycles at $95^{\circ} \mathrm{C}$ for $10 \mathrm{~s}$ and $60^{\circ} \mathrm{C}$ for $30 \mathrm{~s}$. To assess product specificity, amplicons were checked by melting curve analysis. Melting curves were generated from $65^{\circ} \mathrm{C}$ to $95^{\circ} \mathrm{C}$ with increments of $0.3^{\circ} \mathrm{C} /$ cycle. An interrun 
TABLE 2: Details of specific primers used in Real-Time PCR experiments.

\begin{tabular}{|c|c|c|c|c|c|c|}
\hline Gene & Primer sequence & $\begin{array}{l}\text { GenBank, } \\
\text { accession number }\end{array}$ & Amplicon length, bp & Temperature, ${ }^{\circ} \mathrm{C}$ & Efficiency, \% & $R^{2}$ \\
\hline CD39 & $\begin{array}{c}\text { F: CACAGCATAGTAGATTGACAT } \\
\text { R: ATACGCAGACAGAAGGAA }\end{array}$ & NM_001776 & 103 & 60 & 99.8 & 0.998 \\
\hline CD73 & $\begin{array}{l}\text { F: TAAGCACACTGTCTCATT } \\
\text { R: CTGTATGGTCAAGTCAAC }\end{array}$ & NM_002526 & 116 & 60 & 101 & 0.999 \\
\hline$Y W H A Z$ & $\begin{array}{l}\text { F: ATGCAACCAACACATCCTATC } \\
\text { R: GCATTATTAGCGTGCTGTCTT }\end{array}$ & NM_001135702 & 178 & 60 & 95.3 & 0.997 \\
\hline TOP2b & $\begin{array}{l}\text { F: AACTGGATGATGCTAATGATGCT } \\
\text { R: TGGAAAAACTCCGTATCTGTCTC }\end{array}$ & NM_001068 & 137 & 60 & 98.4 & 0.998 \\
\hline SRP14 & $\begin{array}{c}\text { F: CAGATGGCTTATTCAAACCTCCT } \\
\text { R: ATGCCCTTTACTGTGCTGCT }\end{array}$ & NM_003134 & 181 & 60 & 99.9 & 0.998 \\
\hline
\end{tabular}

CD39: ectonucleoside triphosphate diphosphohydrolase; CD73: ecto-5' -nucleotidase; YWHAZ: tyrosine 3-monooxygenase/tryptophan 5-monooxygenase activation protein z polypeptide; TOP2b: topoisomerase II Beta; SRP14: signal recognition particle $14 \mathrm{kDa}$.

calibrator was used to allow comparison of $C_{t}$ values obtained in different runs. The mean standard deviation for $C_{t}$ values was 0.09 . All reactions were performed in duplicate.

\section{Data Analysis}

GeNorm software was used to define the most stably expressed gene set, as previously described $[14,15]$. The geometric mean of the three most stably expressed genes (TOP2b, YWHAZ, and SRP14) was used for normalization of each gene mRNA expression in the samples [16]. The relative quantification was performed by the $\Delta \Delta C_{t}$ method using iQ5 software (BioRad). Differences between more than two independent groups were analyzed by Fisher's test after ANOVA. Differences between two independent groups were assessed by un-paired $t$-test. Relations between variables were assessed by linear regression.

The results are expressed as mean \pm SEM, and $P$ value was considered significant when $<0.05$.

\section{Results and Discussion}

The amount and purity of RNA were evaluated by absorption wavelengths of $260 \mathrm{~nm}$ and $280 \mathrm{~nm}$, and the absorption ratio $\left(A_{260} / A_{280} \mathrm{~nm}\right)$ of all preparations was between 1.9 and 2.1. All samples were subject to gel electrophoresis to prove the integrity of 18 and $28 \mathrm{~S}$ ribosomal RNAs.

In human whole blood of HF patients, a significant increase in the levels of mRNA expression of each AR as a function of clinical severity and compared to $C$ was observed as reported in Figure 1.

To evaluate the catalyzation of the dephosphorylation of adenine nucleotides to adenosine in the extracellular space, the two cell surface molecules CD39 and CD73 were also evaluated.

CD39 and CD73 transcript levels resulted upregulated in human leukocytes of HF patients as a function of clinical severity, although not significantly $(\mathrm{CD} 39$ : $C=0.02 \pm 0.009$,
TABLE 3

\begin{tabular}{lcc}
\hline & $r$ & $P$ \\
\hline $\mathrm{A}_{1} \mathrm{R} / \mathrm{A}_{2 \mathrm{a}} \mathrm{R}$ & 0.69 & $<0.0001$ \\
$\mathrm{~A}_{1} \mathrm{R} / \mathrm{A}_{2 \mathrm{~b}} \mathrm{R}$ & 0.51 & 0.008 \\
$\mathrm{~A}_{1} \mathrm{R} / \mathrm{A}_{3} \mathrm{R}$ & 0.65 & 0.0001 \\
$\mathrm{~A}_{2 \mathrm{a}} \mathrm{R} / \mathrm{A}_{2 \mathrm{~b}} \mathrm{R}$ & 0.84 & $<0.0001$ \\
$\mathrm{~A}_{2 \mathrm{a}} \mathrm{R} / \mathrm{A}_{3} \mathrm{R}$ & 0.83 & $<0.0001$ \\
$\mathrm{~A}_{2 \mathrm{~b}} \mathrm{R} / \mathrm{A}_{3} \mathrm{R}$ & 0.75 & $<0.0001$ \\
\hline
\end{tabular}

NYHA I-II $=0.14 \pm 0.04$, NYHA III-IV $=0.13 \pm 0.07$; CD73: $C=0.15 \pm 0.06$, NYHA I-II $=0.25 \pm 0.1$, NYHA III-IV $=0.31 \pm 0.07)$.

Significant correlations were observed between all ARs themselves (Table 3).

To our knowledge this is the first time that increased AR mRNA expression in the peripheral circulating cells of HF patients compared to healthy subjects has been demonstrated. The increased expression of these ARs appears related to the severity of the disease, as indicated by the progressive rise in mRNA expression values with worsening of symptoms, and which also parallels the degree of LV dilatation and dysfunction as shown by the impairment in LV ejection fraction.

In these patients all four receptor subtypes resulted activated despite their different functions at the cardiovascular level; these results emphasize possible adenosine receptor coregulation and are in line with a recent study which showed that normal cardiac homeostasis requires a stoichiometric balance between signaling through the $A_{1} / A_{3} G \alpha_{i}$ proteincoupled receptors and the $\mathrm{A}_{2 \mathrm{a}} \mathrm{G} \alpha_{\mathrm{s}}$ protein-coupled receptor. The need for "balanced" signaling provides an explanation for how a signaling system - in which a single ligand binds to multiple receptor subtypes-may develop naturally, although some of these active downstream pathways have diametrically opposite cellular effects [17]. 


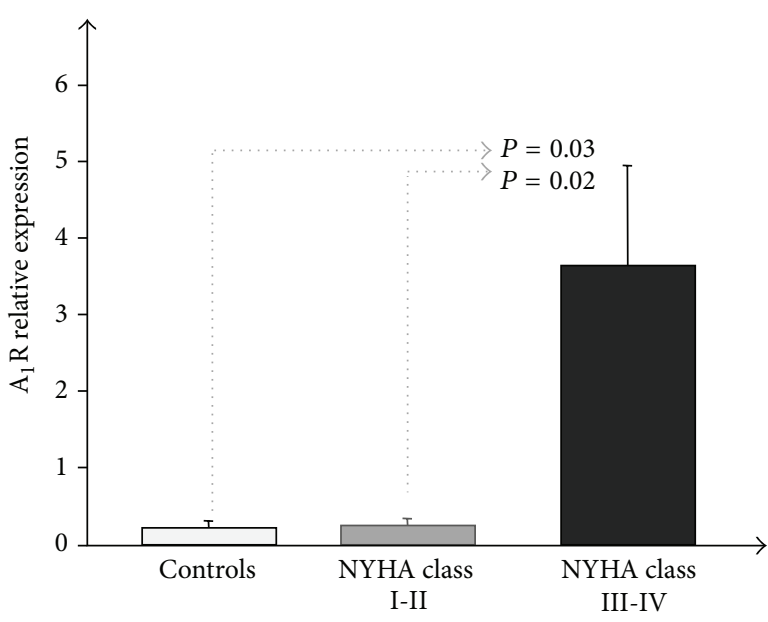

(a)

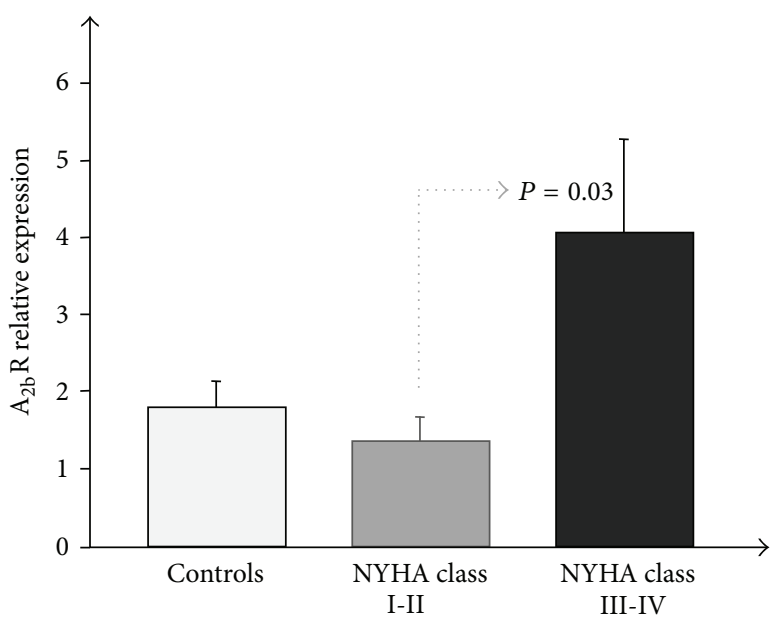

(c)

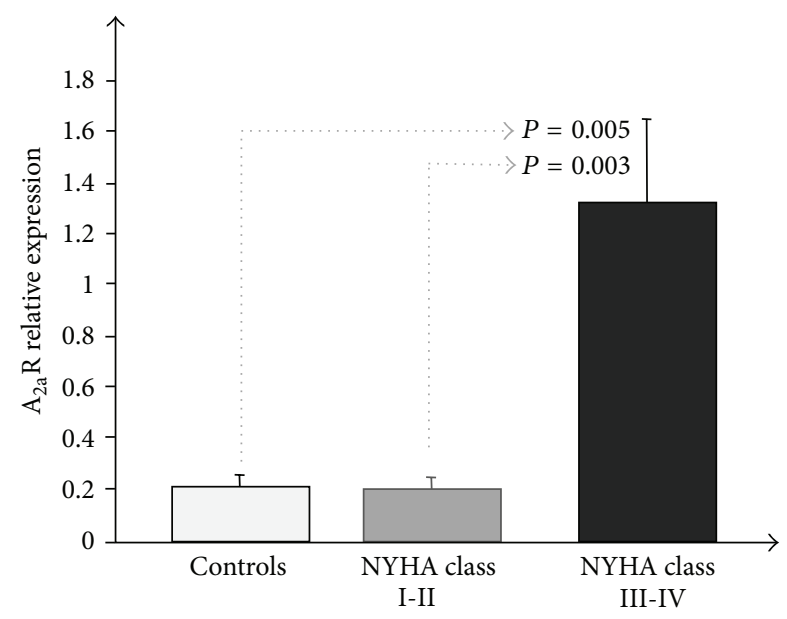

(b)

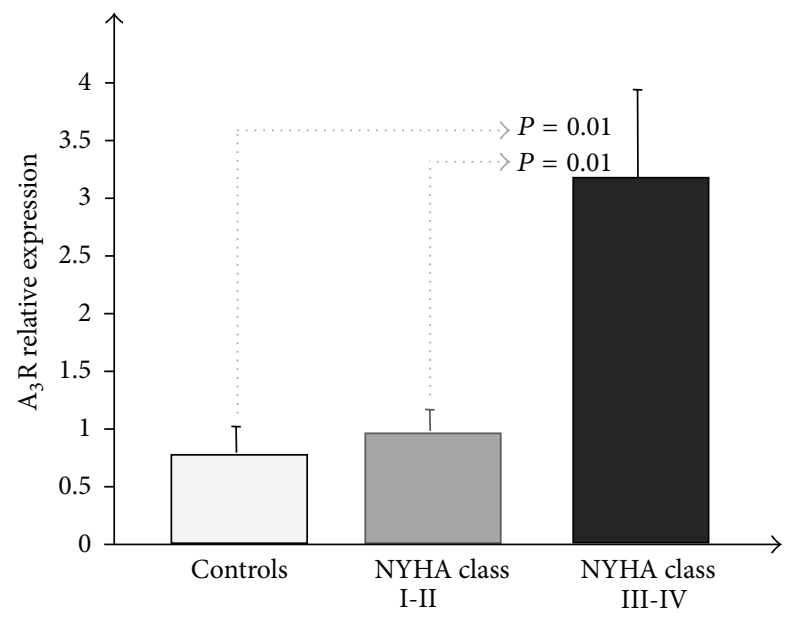

(d)

Figure 1: (a) $A_{1} R$, (b) $A_{2 a} R$, (c) $A_{2 b} R$, and (d) $A_{3} R$ mRNA expression measured by Real-Time PCR in human whole blood of HF patients as a function of clinical severity.

As previously described [11], adenosine plasma levels could be increased in HF patients as a possible consequence of sympathetic activation, as also indirectly shown by CD39 and CD73 upregulation observed in these patients.

Adenosine is mainly present in the cytoplasm in its phosphorylated forms AMP, ADP, and ATP; it is generated through AMP hydrolysis by the CD73 enzyme that represents an integral part of energy regulation at cellular level.s

Under physiological conditions this nucleoside is kept to low concentration at the intracellular level by both Sadenosylhomocysteine and S-adenosylhomocysteine hydrolase [18].

In response to cellular stress and damage, such as metabolic factors, injury, and hypoxia, adenosine is generated in the extracellular space by dephosphorylation of adenine nucleotides released by cells [19], and this dephosphorylation is achieved by a two-step enzymatic process involving the CD39 (conversion of ATP/ADP to AMP) and CD73 (conversion of AMP to adenosine) [20].
Several neurohormonal factors, including catecholamines, renin angiotensin, and cytokines, are involved in the pathophysiology of chronic HF [21-23]. Activation of protein kinase $\mathrm{C}$ from either norepinephrine or angiotensin II activates CD73, and cytokines increase the transcriptional and protein levels of CD73 $[24,25]$ which may lead to increased plasma adenosine levels.

The upregulation of these enzymes is an important purinergic remodeling response in environments where adenosine has been shown to regulate disease [26, 27].

The increased CD39 and CD73 transcript levels observed in this study, with a clear trend despite the lack of statistical significance, suggest a protective CD39-CD73-dependent adenosine production in advanced HF patients.

Adenosine attenuates the release of catecholamines, $\beta$ adrenoceptor-mediated myocardial hypercontraction, and calcium overload via $A_{1}$ receptors. It also increases coronary blood flow and inhibits platelet and leukocyte activation via $A_{2} R$. Furthermore, adenosine inhibits renin release and 
tumor necrosis factor- $\alpha$ production in experimental models $[28,29]$. All these observations may lead to the hypothesis that increased adenosine levels in chronic HF may compensate for the worsening of the disease, suggesting that further elevation of adenosine levels may be beneficial to its pathophysiology. $\beta$-adrenoceptor blockers, angiotensinconverting enzyme inhibitors (ACE-Is), angiotensin receptor blockers, or aldosterone analogs have been proven effective for the treatment of HF in large-scale clinical trials [30, 31], but these strategies are not sufficient to effectively reduce mortality which remains high. Clinical observational studies showed a striking beneficial effect of endogenous adenosine accumulation achieved with oral chronic dipyridamole therapy on symptoms, exercise capacity, and left ventricular function in chronic $\operatorname{HF}[32,33]$. The hypothesis that increased endogenous adenosine accumulation via dipyridamole administration may exert a beneficial effect in HF is attractive; an ancillary anti-inflammatory effect on top of conventional anti-HF therapy would be desirable in an ideal "anti-heart failure" combination of drugs.

Moreover, an increasing body of evidence suggests an amplification of oxidative stress in circulating leukocytes of patients with HF, implying a contribution to the oxidative damage. Adenosine may have the potential to limit the oxidative stress response of leukocyte through an upregulation of $A_{2 a} R[28,29,34]$ suggesting that HF patients might benefit from a pharmacologic manipulation of $\mathrm{A}_{2 \mathrm{a}} \mathrm{R}$ pathway in order to prevent exacerbations of cytotoxic leukocytes functions.

The results of this study are in line with previous ones performed in normal and failing minipig hearts $[35,36]$ and in peripheral blood mononuclear cells (PBMC) obtained by chronic heart failure patients [11, 12] but are in contrast with the study published by Asakura et al. [37] in which a downregulation of adenosine receptors was observed in the failing myocardium of chronic heart failure patients. The differences between the results of that study and ours remain unknown but may be attributable to the various degrees of severity of HF, the underlying causes of the disease, the normalization of RT-PCR results and a possible desensitization of adenosine receptors subtypes in presence of high adenosine concentrations [38, 39].

RT-PCR is the benchmark method for measuring mRNA expression levels, but the accuracy and reproducibility of its data greatly depend on appropriate normalization strategies. In order to avoid a confounding effect due to reference gene variability between samples, of the many strategies suggested $[40,41]$, the assessment of genes which are most stably expressed among a set of carefully selected targets [14] is considered the most reliable approach.

\section{Conclusion}

The findings of this study show that components of adenosine metabolism and signalling are altered to promote adenosine production in HF patients as a function of clinical severity. These changes include the upregulation of CD39-CD73 and elevations in each of the four AR subtypes. These data provide proof of the concept that adenosine-based drugs may play a role in the treatment of HF patients, after confirmation by randomized clinical trials.

\section{References}

[1] S. Gessi, K. Varani, S. Merighi et al., "Adenosine and lymphocyte regulation," Purinergic Signalling, vol. 3, no. 1-2, pp. 109-116, 2007.

[2] B. B. Fredholm, A. P. IJzerman, K. A. Jacobson, J. Linden, and C. E. Müller, "International union of basic and clinical pharmacology. LXXXI. Nomenclature and classification of adenosine receptors-an update," Pharmacological Reviews, vol. 63, no. 1, pp. $1-34,2011$.

[3] M. Katebi, M. Soleimani, and B. N. Cronstein, "Adenosine a2A receptors play an active role in mouse bone marrow-derived mesenchymal stem cell development," Journal of Leukocyte Biology, vol. 85, no. 3, pp. 438-444, 2009.

[4] M. C. Montesinos, P. Gadangi, M. Longaker et al., "Wound healing is accelerated by agonists of adenosine A2 $(\mathrm{G}(\alpha \mathrm{s})$ linked) receptors," Journal of Experimental Medicine, vol. 186, no. 9, pp. 1615-1620, 1997.

[5] R. Zucchi, G. Yu, S. Ghelardoni, F. Ronca, and S. Ronca-Testoni, "A3 adenosine receptor stimulation modulates sarcoplasmic reticulum $\mathrm{Ca}^{2+}$ release in rat heart," Cardiovascular Research, vol. 50, no. 1, pp. 56-64, 2001.

[6] S. A. Epperson, L. L. Brunton, I. Ramirez-Sanchez, and F. Villarreal, "Adenosine receptors and second messenger signaling pathways in rat cardiac fibroblasts," American Journal of Physiology, vol. 296, no. 5, pp. C1171-C1177, 2009.

[7] M. Wakeno, T. Minamino, O. Seguchi et al., "Long-term stimulation of adenosine $\mathrm{A} 2 \mathrm{~b}$ receptors begun after myocardial infarction prevents cardiac remodeling in rats," Circulation, vol. 114, no. 18, pp. 1923-1932, 2006.

[8] K. Dickstein, P. E. Vardas, A. Auricchio et al., "2010 Focused Update of ESC Guidelines on device therapy in heart failure: an update of the 2008 ESC Guidelines for the diagnosis and treatment of acute and chronic heart failure and the 2007 ESC Guidelines for cardiac and resynchronization therapydeveloped with the special contribution of the Heart Failure Association and the European Heart Rhythm Association," Europace, vol. 12, no. 11, pp. 1526-1536, 2010.

[9] M. M. Redfield, S. J. Jacobsen, J. C. Burnett Jr., D. W. Mahoney, K. R. Bailey, and R. J. Rodeheffer, "Burden of systolic and diastolic ventricular dysfunction in the community: appreciating the scope of the heart failure epidemic," The Journal of the American Medical Association, vol. 289, no. 2, pp. 194-202, 2003.

[10] O. Brodde, J. J. Beckeringh, and M. C. Michel, "Human heart $\beta$ adrenoceptors: a fair comparison with lymphocyte $\beta$-adrenoceptors?" Trends in Pharmacological Sciences, vol. 8, no. 10, pp. 403-407, 1987.

[11] K. Varani, F. Laghi-Pasini, A. Camurri et al., "Changes of peripheral A2A adenosine receptors in chronic heart failure and cardiac transplantation," The FASEB Journal, vol. 17, no. 2, pp. 280-282, 2003.

[12] P. L. Capecchi, A. Camurri, G. Pompella et al., "Upregulation of A2A adenosine receptor expression by TNF- $\alpha$ in PBMC of patients with CHF: a regulatory mechanism of inflammation," Journal of Cardiac Failure, vol. 11, no. 1, pp. 67-73, 2005.

[13] L. Sabatino, M. Cabiati, C. Caselli, and S. Del Ry, "Adenosine receptor expression and gene reference evaluation in human leukocytes," Clinical Laboratory, vol. 59, pp. 571-577, 2013. 
[14] J. Vandesompele, K. De Preter, F. Pattyn et al., "Accurate normalization of real-time quantitative RT-PCR data by geometric averaging of multiple internal control genes," Genome Biology, vol. 3, no. 7, Article ID RESEARCH0034, 2002.

[15] A. Martino, M. Cabiati, M. Campan et al., "Selection of reference genes for normalization of real-time PCR data in minipig heart failure model and evaluation of TNF- $\alpha$ mRNA expression," Journal of Biotechnology, vol. 153, no. 3-4, pp. 92-99, 2011.

[16] M. Cabiati, L. Sabatino, R. Caruso et al., "Gene expression of C-type natriuretic peptide and of its specific receptor NPRB in human leukocytes of healthy and heart failure subjects," Peptides, vol. 37, no. 2, pp. 240-246, 2012.

[17] A. M. Feldman, E. Cheksis-Feiner, E. Hamad, and T. Chan, "Adenosine receptor subtypes and the heart failure phenotype: translating lessons from mice to man," Transactions of the American Clinical and Climatological Association, vol. 122, pp. 198-214, 2011.

[18] L. Antonioli, M. Fornai, R. Colucci et al., "Pharmacological modulation of adenosine system: novel options for treatment of inflammatory bowel diseases," Inflammatory Bowel Diseases, vol. 14, no. 4, pp. 566-574, 2008.

[19] B. N. Cronstein, "Adenosine receptors and fibrosis: a translational review," F1000 Biology Reports, vol. 3, no. 1, p. 21, 2011.

[20] J. Reutershan, I. Vollmer, S. Stark, R. Wagner, K. Ngamsri, and H. K. Eltzschig, "Adenosine and inflammation: CD39 and CD73 are critical mediators in LPS-induced PMN trafficking into the lungs," FASEB Journal, vol. 23, no. 2, pp. 473-482, 2009.

[21] D. E. Vatner, K. Asai, M. Iwase et al., "Beta-adrenergic receptor$G$ protein-adenylyl cyclase signal transduction in the failing heart," The American Journal of Cardiology, vol. 83, no. 12, pp. 80, supplement 1-85, 1999.

[22] M. R. Mehra, P. A. Uber, and S. Potluri, "Renin angiotensin aldosterone and adrenergic modulation in chronic heart failure: contemporary concepts," American Journal of the Medical Sciences, vol. 324, no. 5, pp. 267-275, 2002.

[23] P. Aukrust, L. Gullestad, T. Ueland, J. K. Damås, and A. Yndestad, "Inflammatory and anti-inflammatory cytokines in chronic heart failure: potential therapeutic implications," $A n$ nals of Medicine, vol. 37, no. 2, pp. 74-85, 2005.

[24] H. Funaya, M. Kitakaze, K. Node, T. Minamino, K. Komamura, and M. Hori, "Plasma adenosine levels increase in patients with chronic heart failure," Circulation, vol. 95, no. 6, pp. 1363-1365, 1997.

[25] V. Savic, V. Stefanovic, N. Ardaillou, and R. Ardaillou, "Induction of ecto- $5^{\prime}$-nucleotidase of rat cultured mesangial cells by interleukin- $\beta$ and tumour necrosis factor- $\alpha$, Immunology, vol. 70, no. 3, pp. 321-326, 1990.

[26] Y. Zhou, J. N. Murthy, D. Zeng, L. Belardinelli, and M. R. Blackburn, "Alterations in adenosine metabolism and signaling in patients with chronic obstructive pulmonary disease and idiopathic pulmonary fibrosis," PLoS ONE, vol. 5, no. 2, Article ID e9224, 2010.

[27] M. Fujita, M. Asakura, S. Sanada et al., "Activation of ecto-5' nucleotidase in the blood and hearts of patients with chronic heart failure," Journal of Cardiac Failure, vol. 14, no. 5, pp. 426430, 2008.

[28] M. Lagerkranser, A. Sollevi, and L. Irestedt, "Renin release during controlled hypotension with sodium nitroprusside, nitroglycerin and adenosine: a comparative study in the dog," Acta Anaesthesiologica Scandinavica, vol. 29, no. 1, pp. 45-49, 1985.

[29] M. G. Bouma, F. A. J. M. van den Wildenberg, and W. A. Buurman, "Adenosine inhibits cytokine release and expression of adhesion molecules by activated human endothelial cells," American Journal of Physiology, vol. 270, no. 2, pp. C522-C529, 1996.

[30] M. Packer, "Current role of beta-adrenergic blockers in the management of chronic heart failure," American Journal of Medicine, vol. 110, no. 7, 2001.

[31] A. T. Yan, R. T. Yan, and P. P. Liu, "Narrative review: pharmacotherapy for chronic heart failure: evidence from recent clinical trials," Annals of Internal Medicine, vol. 142, no. 2, pp. 132-145, 2005.

[32] M. Kitakaze, T. Minamino, K. Node et al., "Elevation of plasma adenosine levels may attenuate the severity of chronic heart failure," Cardiovascular Drugs and Therapy, vol. 12, no. 3, pp. 307309, 1998.

[33] M. Akhtar, K. Ordovas, A. Martin, C. B. Higgins, and A. D. Michaels, "Effect of chronic sustained-release dipyridamole on myocardial blood flow and left ventricular function in patients with ischemic cardiomyopathy," Congestive Heart Failure, vol. 13, no. 3, pp. 130-135, 2007.

[34] I. Kaufmann, A. Hoelzl, F. Schliephake et al., "Effects of adenosine on functions of polymorphonuclear leukocytes from patients with septic shock," Shock, vol. 27, no. 1, pp. 25-31, 2007.

[35] S. Del Ry, M. Cabiati, A. Martino, A. Simioniuc, M. Morales, and E. Picano, "Adenosine receptor mRNA expression in normal and failing minipig hearts," Journal of Cardiovascular Pharmacology, vol. 58, no. 2, pp. 149-156, 2011.

[36] S. Del Ry, M. Cabiati, V. Lionetti et al., "Pacing-induced regional differences in adenosine receptors mRNA expression in a swine model of dilated cardiomyopathy," PLoS ONE, vol. 7, no. 10, Article ID e47011, 2012.

[37] M. Asakura, H. Asanuma, J. Kim et al., "Impact of adenosine receptor signaling and metabolism on pathophysiology in patients with chronic heart failure," Hypertension Research, vol. 30, no. 9, pp. 781-787, 2007.

[38] E. C. Klaasse, A. P. IJzerman, W. J. de Grip, and M. W. Beukers, "Internalization and desensitization of adenosine receptors," Purinergic Signalling, vol. 4, no. 1, pp. 21-37, 2008.

[39] B. D. Hettinger, M. Leid, and T. F. Murray, "Cyclopentyladenosine-induced homologous down-regulation of Al adenosine receptors (A1AR) in intact neurons is accompanied by receptor sequestration but not a reduction in A1AR mRNA expression or G protein $\alpha$-subunit content," Journal of Neurochemistry, vol. 71, no. 1, pp. 221-230, 1998.

[40] J. Huggett, K. Dheda, S. Bustin, and A. Zumla, "Real-time RTPCR normalisation; strategies and considerations," Genes and Immunity, vol. 6, no. 4, pp. 279-284, 2005.

[41] S. Derveaux, J. Vandesompele, and J. Hellemans, "How to do successful gene expression analysis using real-time PCR," Methods, vol. 50, no. 4, pp. 227-230, 2010. 


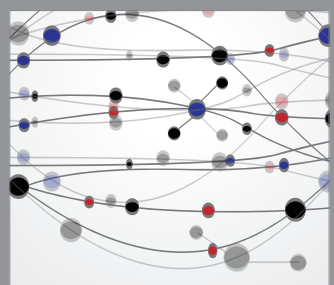

The Scientific World Journal
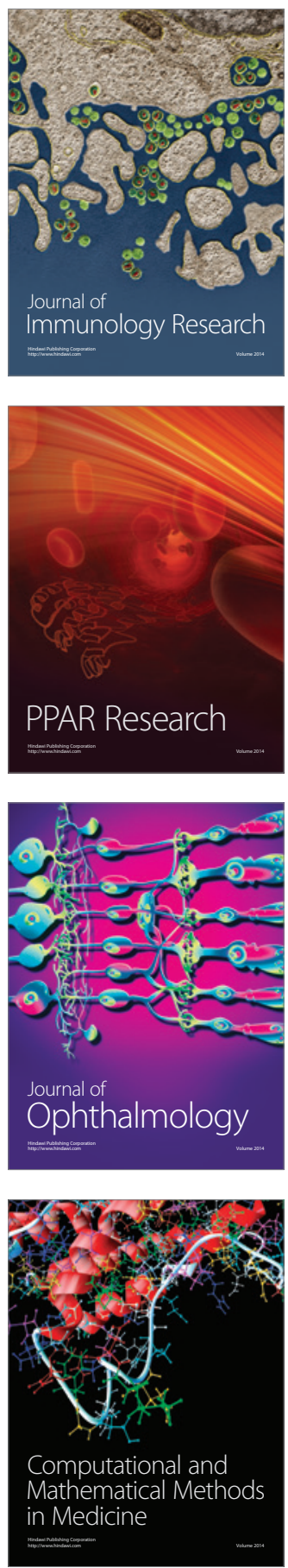

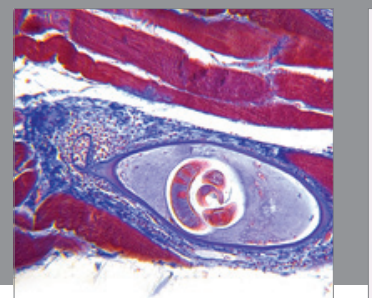

Gastroenterology

Research and Practice
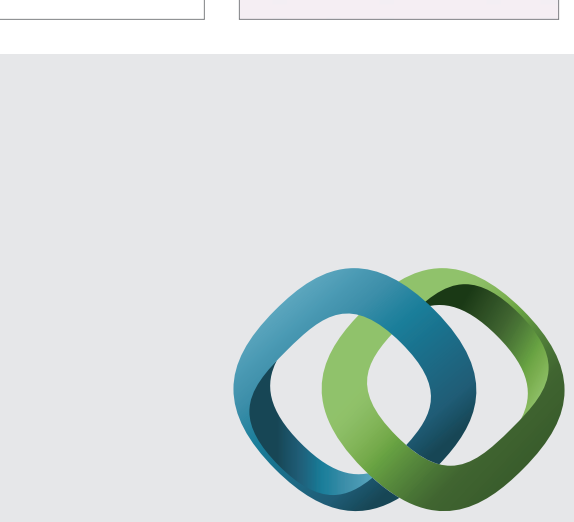

\section{Hindawi}

Submit your manuscripts at

http://www.hindawi.com
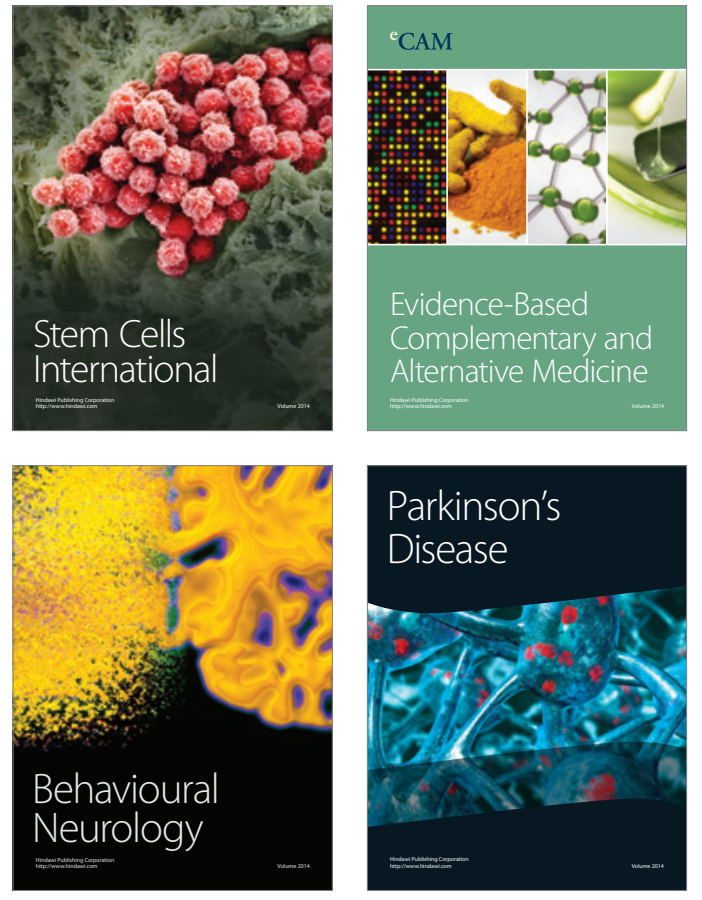
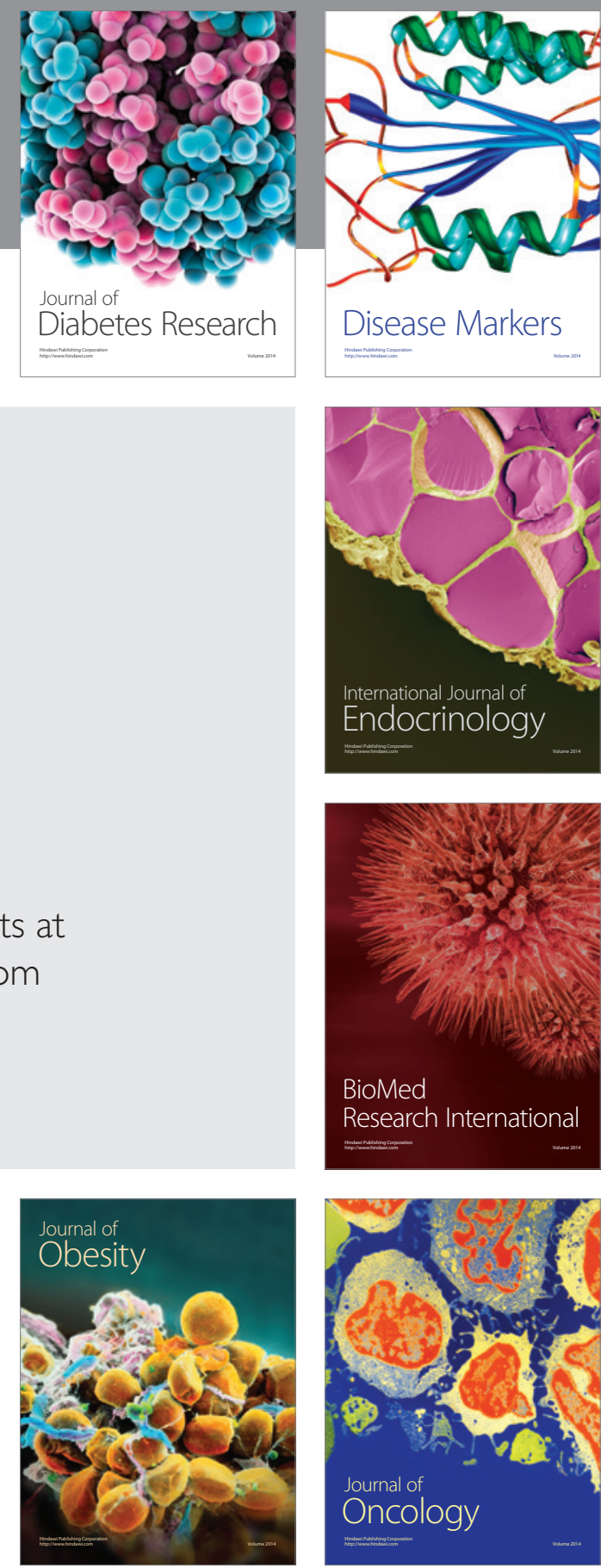

Disease Markers
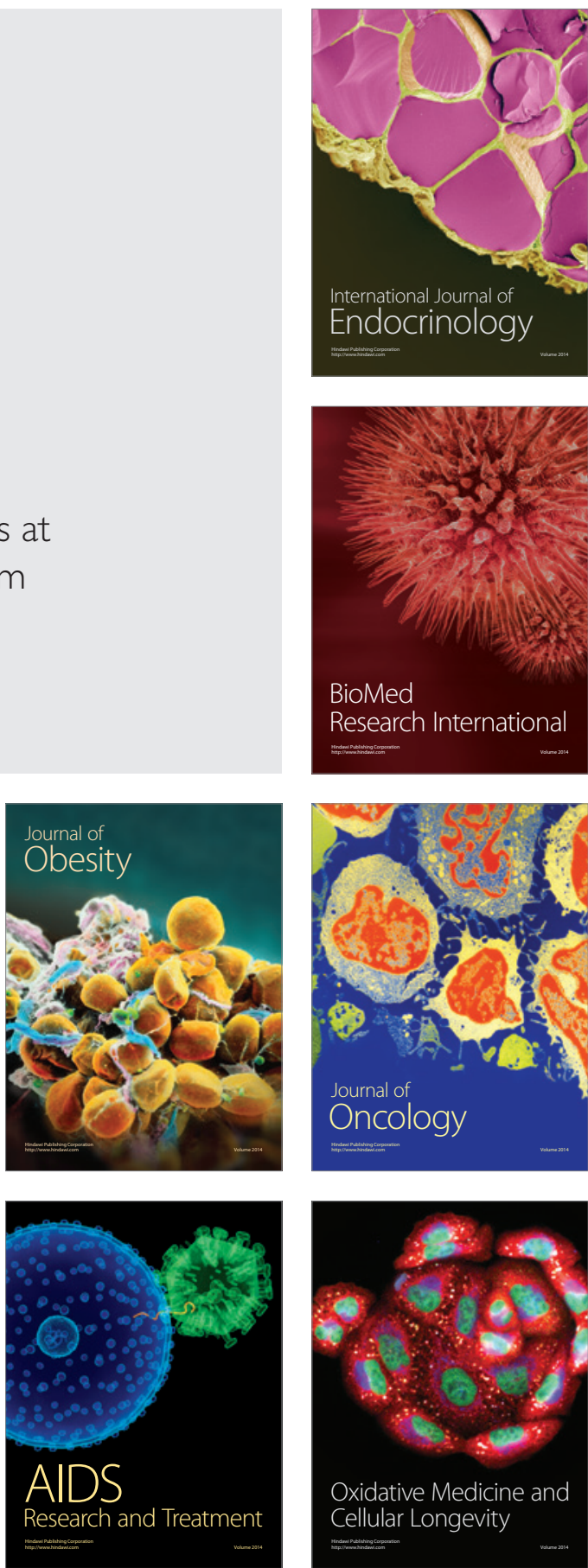